\title{
Observations on Speke Glacier, Ruwenzori Range, Uganda
}

\author{
GeORg Kaser AND Bernd Noggler \\ Department of Geography, University of Innsbruck, A-6020 Innsbruck, Austria
}

\begin{abstract}
Speke Glacier, the best studied and largest single glacier in the Ruwenzori Range (Uganda, East Africa), was revisited in January 1990. A comparison of its present state with former observations reveals that its terminus receded $35-45 \mathrm{~m}$ between 1958 and 1977; since 1977 it has retreated more than $150 \mathrm{~m}$. Nearly half the width of the snout has been lost, mainly on its western side, and the entire western section of the south-facing glacier has shrunk substantially. The observed fluctuation conforms with changes occurring on other tropical glaciers. Explanations concerning the reasons for the glacier recession are presented.
\end{abstract}

\section{INTRODUGTION}

Mount Speke $(4890 \mathrm{~m})$ is one of the six ice-capped mountains of the Ruwenzori Range, Uganda, situated at approximately $0^{\circ} 30^{\prime} \mathrm{N}, 30^{\circ} \mathrm{E}$ (Fig. 1). The mountain range reaches its highest elevation of $5109 \mathrm{~m}$ on Margherita Peak, Mount Stanley, and the lowest recent glacier terminus positions are located below $4400 \mathrm{~m}$.

Haeberli and others (1989), citing Messerli (1980), identified 30 glacier units covering a total area of $4.96 \mathrm{~km}^{2}$, whereas Hastenrath (1984), citing Whittow and others (1963), Temple (1968), Osmaston and Pasteur (1972), and his own observations in 1974 spoke of 44 separate ice bodies with an area of $3.9 \mathrm{~km}^{2}$. Whittow and others (1963) recorded the existence of 37 Ruwenzori glaciers with a total glacier area of slightly less than $5 \mathrm{~km}^{2}$. Whittow and others (1963) also reported snow-line altitudes of $15000 \mathrm{ft}$ (approximately $4570 \mathrm{~m}$ ) on the eastern slopes and $15600 \mathrm{ft}$ (approximately $4750 \mathrm{~m}$ ) on the western slopes, respectively.

The largest coherent ice bodies are the remnant summit ice caps on Mount Stanley and Mount Speke, whereas the largest single valley glacier is south-facing Speke Glacier of Mount Speke. Speke Glacier was the subject of our visit in January 1990.

Following the detailed reports of the exploration of Abruzzi's expedition in 1906, including the excellent photographs of Vittorio Sella and the first valid topographical map of the Ruwenzori Range (Luigi Amadeo. Duke of the Abruzzi, 1909; Fiory-Ceccopieri, 1981), several reports of later Ruwenzori expeditions have yielded only an approximate knowledge about glacier recession (e.g. Humphreys, 1927, 1933; Menzies, 1951).

The first serious glaciological studies were carried out by E. Bergström, a member of the British Ruwenzori Expedition 1952 (Bergström, 1955). He pointed out that two ablation periods per year during the so-called "dry" seasons of January-February and June-August and two wet seasons dominate the glacial regime on Ruwenzori. Intensive glaciological investigations were performed by the members of Makarere University College of Uganda on Elena and Savoia Glaciers of Mount Stanley, Moore Glacier of Mount Baker and Speke Glacier of Mount Speke during six expeditions between 1957 and 1961

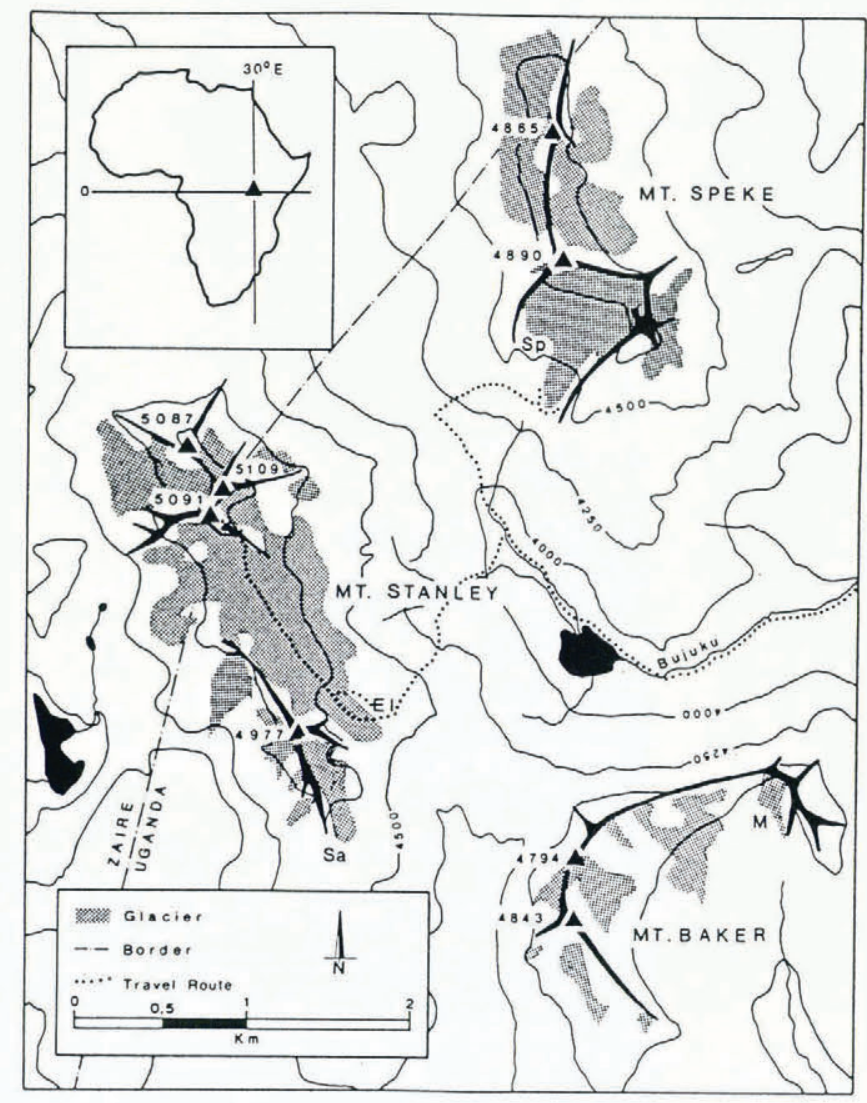

Fig. 1. The ice-covered mountains of the central Ruwenzori, Uganda. Sp, Speke Glacier; El, Elena Glacier; Sa, Savoia Glacier; M, Moore Glacier (after Wielochowsky, 1989). 
(Whittow, 1959, 1960; Whittow and others, 1963). Temple (1968) extended these investigations to 1967.

Comprehensive summaries of glaciological investigations on Ruwenzori and lists of pertinent literature, photographic comparisons and topographical maps have been given by Whittow and others (1963), Osmaston and Pasteur (1972) and Hastenrath (1984). The most recent photographs of Ruwenzori glaciers include those of Hastenrath from 1974 (Hastenrath, 1984) and Lichtenegger from 1977 (Lichtenegger and Lichtenegger, 1978).

\section{SPEKE GLACIER}

Speke glacier is the largest and also the best studied glacier of Ruwenzori. According to Whittow and others (1963), Speke Glacier covered an area of approximately $0.357 \mathrm{~km}^{2}$, reaching from the Mount Speke summit crest at $4814 \mathrm{~m}$ to the terminus at $4344 \mathrm{~m}$. Assuming a permanent firn-line altitude of $4570 \mathrm{~m}$, the accumulation area of the south-facing glacier was estimated to be twice as large as the ablation area.

In June 1958 and June 1959, cairns and stone markers were established immediately in front of the glacier tongue to facilitate measurements of terminus changes in June 1958, January 1959, June 1959, January 1960 (Whittow and others, 1963), July 1961, March 1962, December 1962, December 1963 and January 1967 (Temple, 1968). Between June 1958 and January 1967, a net recession of approximately $11 \mathrm{~m}$ was recorded. However, between July 1961 and March 1962 the terminus advanced by $3.5 \mathrm{~m}$ (Temple, 1968). A similar advance was also observed at Elena Glacier. Temple (1968) and Osmaston and Pasteur (1972) have suggested that increased precipitation was responsible for these advances.

Small advances of the eastern part of the glacier tongue were also observed between June 1958 and
January 1959 and between June 1959 and January 1960.

As a result of these observations, Whittow and others (1963) predicted that Speke Glacier would shrink to a small remnant ice body above $4600 \mathrm{~m}$ by the end of the century.

\section{OBSERVATIONS AND RESULTS}

Our initial impression of Speke Glacier during our visit in January 1990 was that of a generally shrunken glacier with a terminus that had undergone a significant retreat (Fig. 2). A lake measuring approximately $120 \times 140 \mathrm{~m}$ had developed behind a ridge of solid rock in front of the glacier.

Small moraines formed of rather large boulders deposited upon this ridge furnish evidence of the 196162 advance and, in comparison with the 1974 photograph of Hastenrath (1984), of an advance or at least a longer steady state around 1974 . Behind this ridge no further signs of moraine formation were found. Osmaston and Pasteur (1972) explained the general lack of moraines as due to a combination of the hardness of the rock and temperature variations that are too small to cause significant rock shattering.

Between the above-mentioned moraines and the actual terminus no vegetation exists except a very few newly grown lichens.

A number of ice blocks dot the area between the glacier terminus and the lake. Evidently, the ice blocks are the result of a thinning-out process of the glacier tongue.

The two survey points of June 1958 and the one of June 1959 recorded on the map of Whittow and others (1963) were easily located, and after searching for them, the painted stones B, C, D and G were rediscovered under a dense lichen cover. A comprehensive series of photographs was taken from different survey points, including a

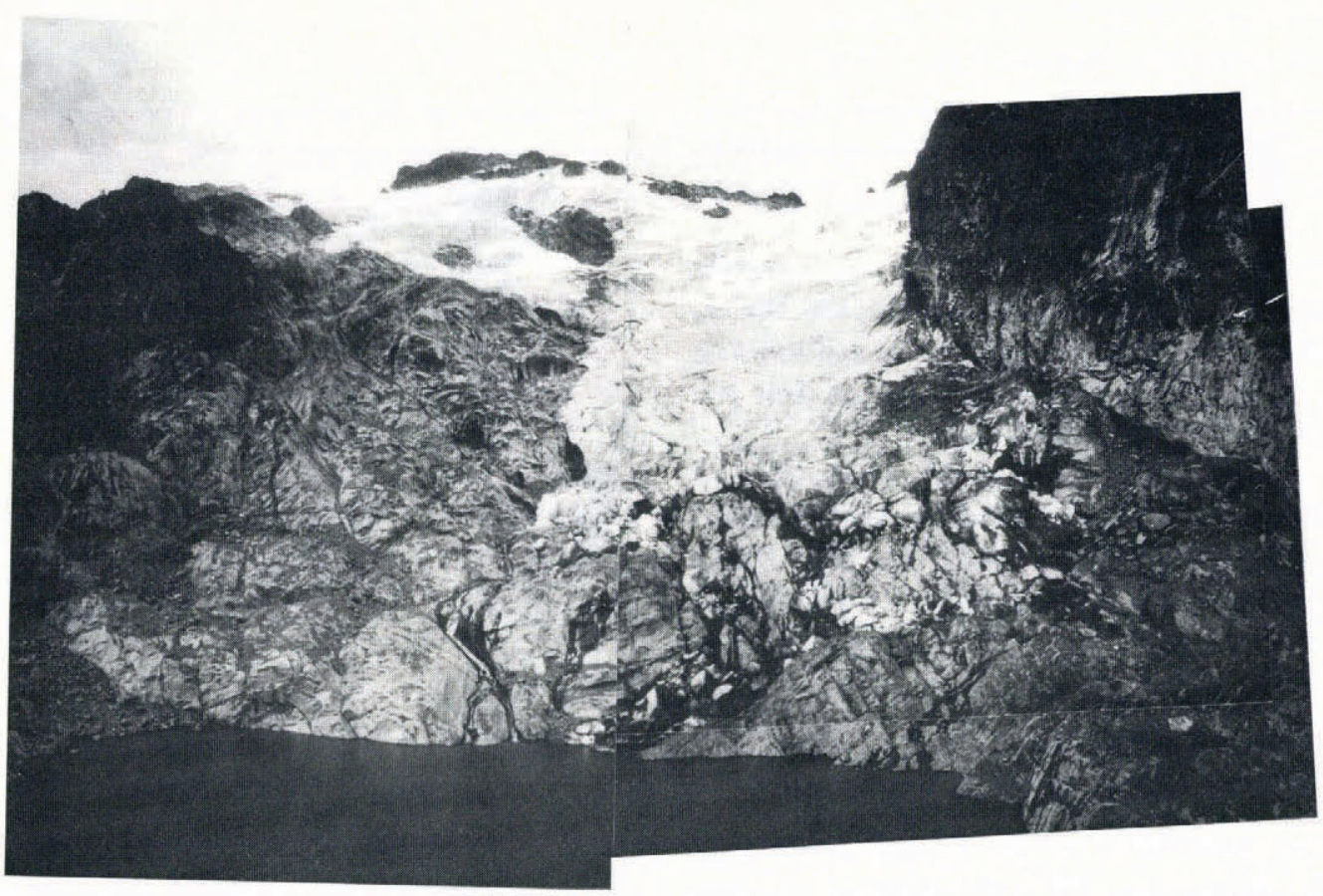

Fig. 2. Speke Glacier seen from point P (see Fig. 5). Photograph taken by the authors on 29 January 1990. 


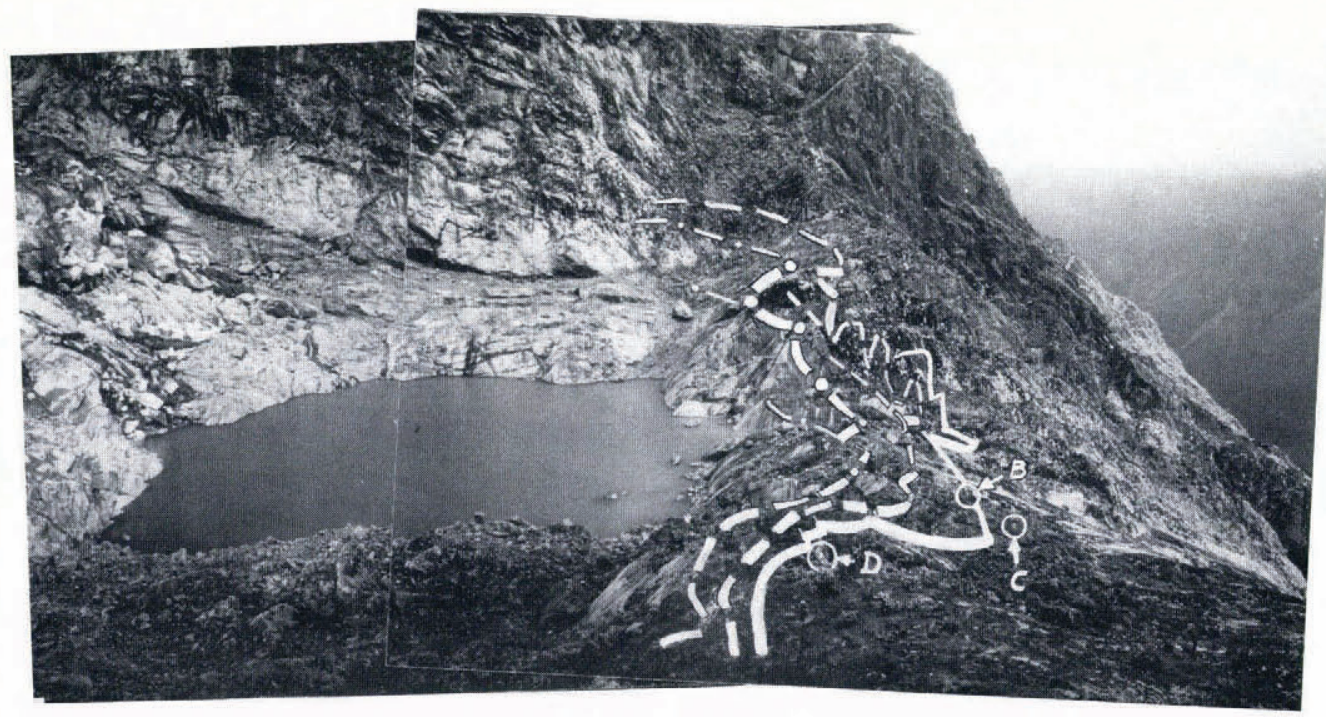

Fig. 3. Terminus positions of Speke Glacier observed from survey point 2 (see Fig. 5). Solid line, June 1958; broken line, July 1961 (both after Whittow and others, 1963); dotted line, January 1974 (after Hastenrath, 1984). Marks $D$ (note the person sitting on the stone; the mark itself is hidden behind a plant), B and C from left are circled. Photograph taken by the authors on 29 January 1990.

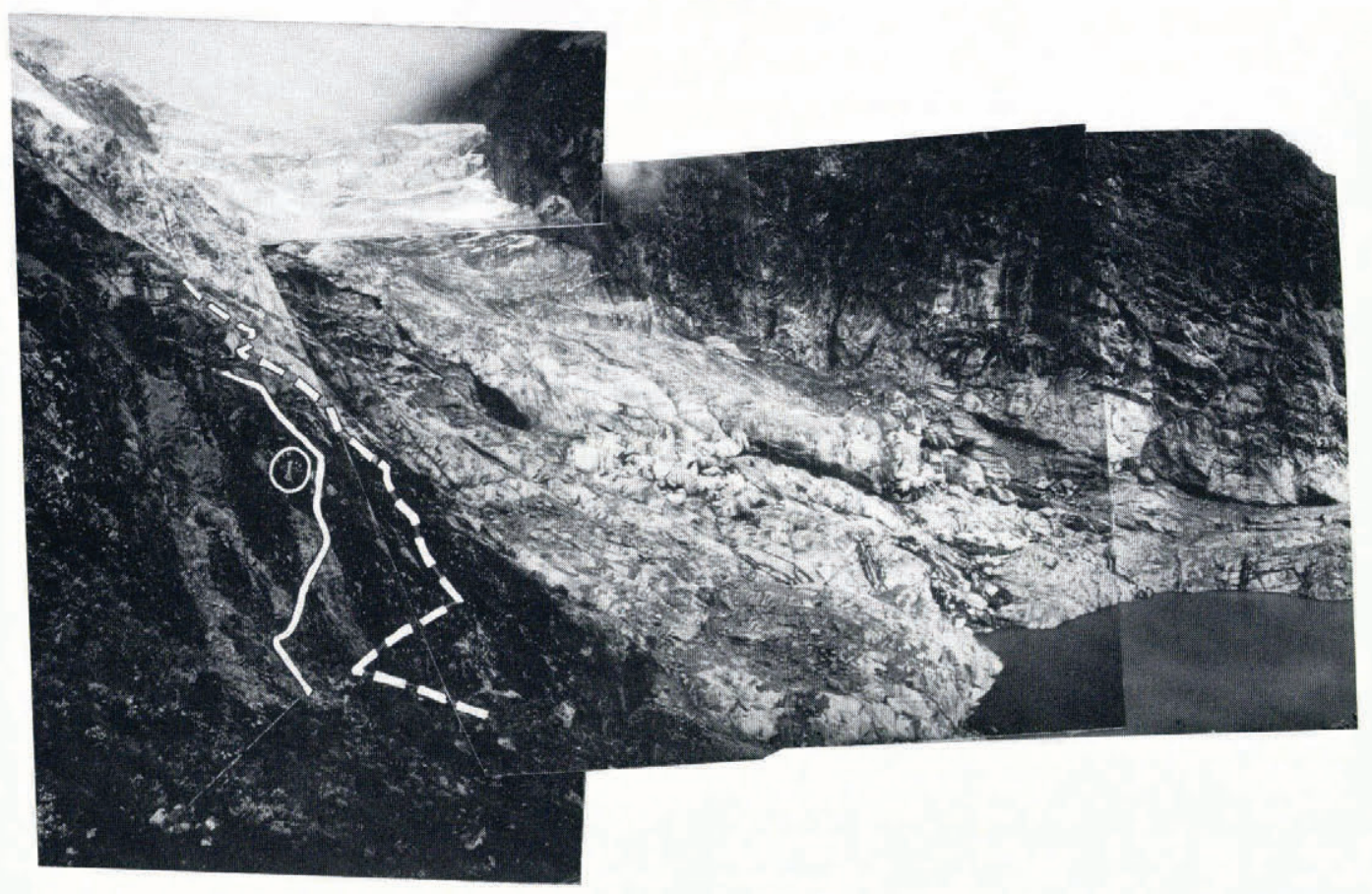

Fig. 4. Terminus positions of Speke Glacier as seen from survey point 1 (see Fig. 5). Lines and references are the same as in Figure 3. Mark $G$ is circled. Photograph taken by the authors on 29 January 1990.

pair of stereo photographs of the glacier tongue. The distance between mark $\mathrm{D}$ and the actual terminus was tape-measured.

Figures 3 and 4 show the present and former tongue positions of Speke Glacier from different locations. The ice-front positions in June 1958, July 1961 and January 1974 were drawn with reference to comparable photographs published by Whittow and others (1963) and Hastenrath (1984). The position of the glacier tongue in January 1967 (Temple, 1968) which was situated midway between that of July 1961 and January 1974 is not shown for reasons of clarity.
Figure 5, showing the retreat of the terminus of Speke Glacier between 1950 and 1990, is based on the map of Whittow and others (1963, p. 594). The 1990 situation was constructed on the basis of field notes, measured distances, lateral and frontal photographs as shown in Figures 2, 3 and 4 and the stereo photographs.

Figure 6 gives an overall view of Speke Glacier as seen from Albert Peak (5087 m) on Mount Stanley. The white line is bared as a comparison of photographs obtained in 1967 (Temple, 1968), 1974 (Hastenrath, 1984) and 1977 (Lichtenegger and Lichtenegger, 1978). Although there were no distinguishable variations in the extent of the ice- 


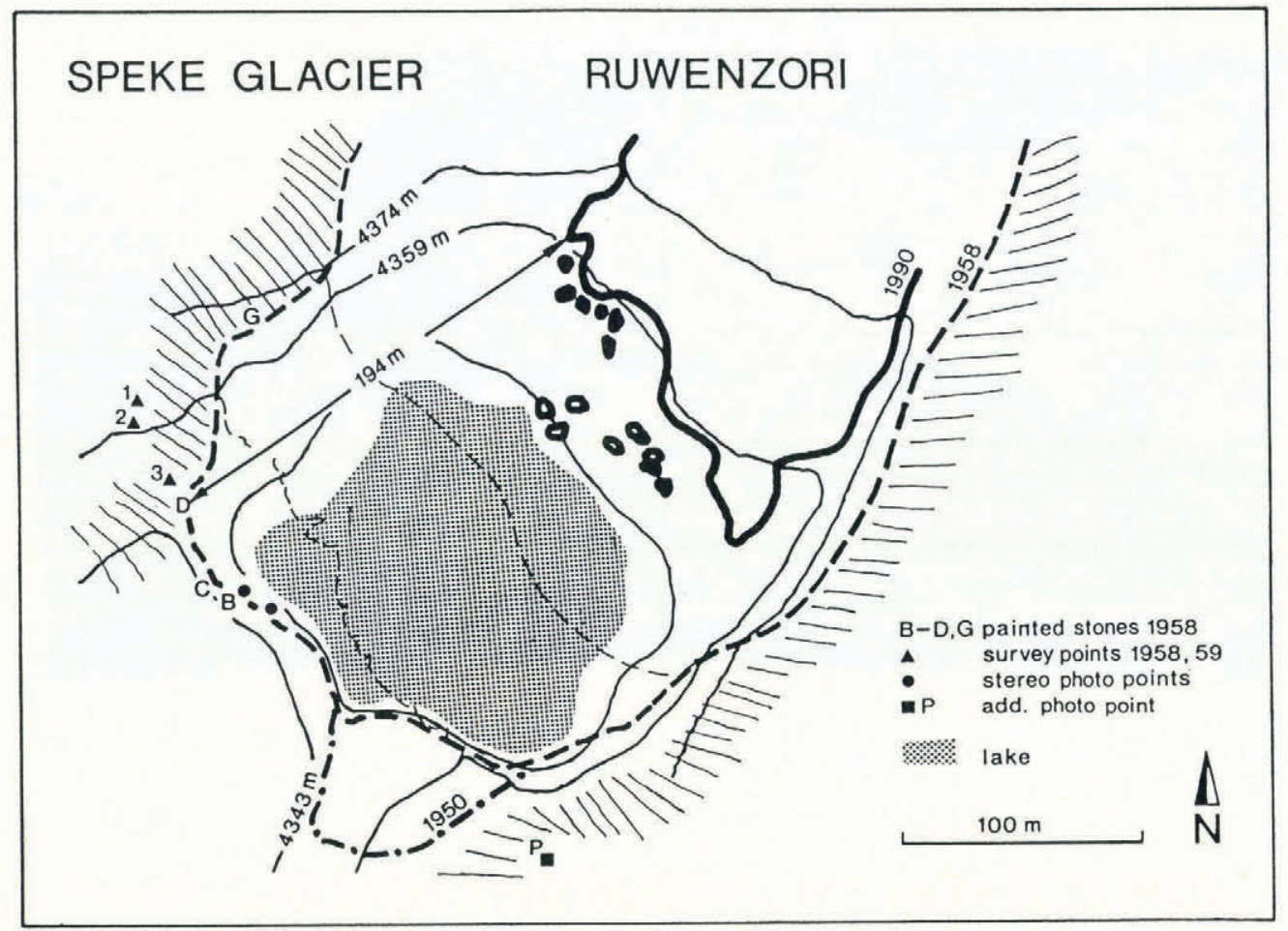

Fig. 5. The terminus positions of Speke Glacier in 1950 (after Menzies, 1951), 1958 (after Whittow and others, 1963) and January 1990. The figure is based on the map of Whittow and others (1963, p. 594).

covered surface between 1967 and 1977, a thinning of the western part of the serac zone occurred at approximately $4700 \mathrm{~m}$. By 1990 this western serac zone had disappeared along with almost half the tongue on the western side of Speke Glacier. By contrast, the eastern part of the serac zone is still as thick and active as it was in 1967. A comparison of all four photographs taken between 1967 and 1990 gives the general impression of a very substantial

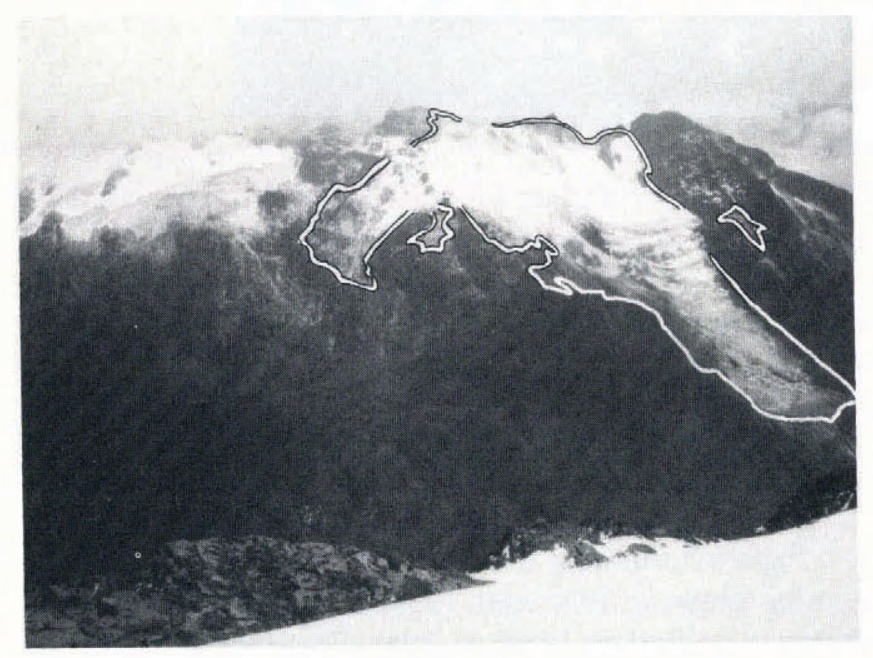

Fig. 6. Speke Glacier as seen from Albert Peak on Mount Stanley. The white line indicates the extent of Speke Glacier as reconstructed on the basis of photographs taken in 1967 (Temple, 1968), 1974 (Hastenrath, 1984) and 1977 (Lichtenegger and Lichtenegger, 1978). During this period no marked variations in the extent of the ice could be seen from the photographs. Photograph taken by H. Wagner on 29 January 1990. shrinkage of the whole western section of Speke Glacier at the same time that the eastern section was maintaining an active state.

The prediction of Whittow and others (1963) that Speke Glacier would shrink to a remnant ice body above $4600 \mathrm{~m}$ within this century is already being realized for the western section of Speke Glacier, while at the same time the eastern section has undergone minimal changes.

Variations in the terminus of Speke Glacier (referenced to mark D) are shown in Figure 7. Earlier data are taken from Temple (1968) and Hastenrath (1984), whereas the 1977 value was reconstructed from a photograph published by Lichtenegger and Lichtenegger (1978). Hastenrath (1984) reported his assessment of a 30$40 \mathrm{~m}$ retreat of the snout of Speke Glacier between 1958 and 1974 , and a lateral shrinkage of $10-20 \mathrm{~m}$ in the same period. Compared to the 1974 state, a 5-10 m retreat was estimated by 1977. Although minor advances have occurred, Figure 7 shows a net recession of the terminus of approximately $45 \mathrm{~m}$ between 1958 and 1977 followed by a retreat of $150 \mathrm{~m}$ since then. Compared to its total length of $1 \mathrm{~km}$ (Hastenrath, 1984), the retreat of Speke Glacier since 1958 represents a loss of about $20 \%$.

\section{DISCUSSION AND GONCLUSIONS}

The recent substantial retreat of Speke Glacier correlates well with observations elsewhere in the world and especially with those of tropical areas (Allison and Peterson, 1976, 1989; Hastenrath, 1984; Patzelt, 1987; Hastenrath and others, 1989; Kaser and others, 1990). In particular, the significant shrinkage of Speke Glacier since 1977 corresponds closely with the extreme mass loss 


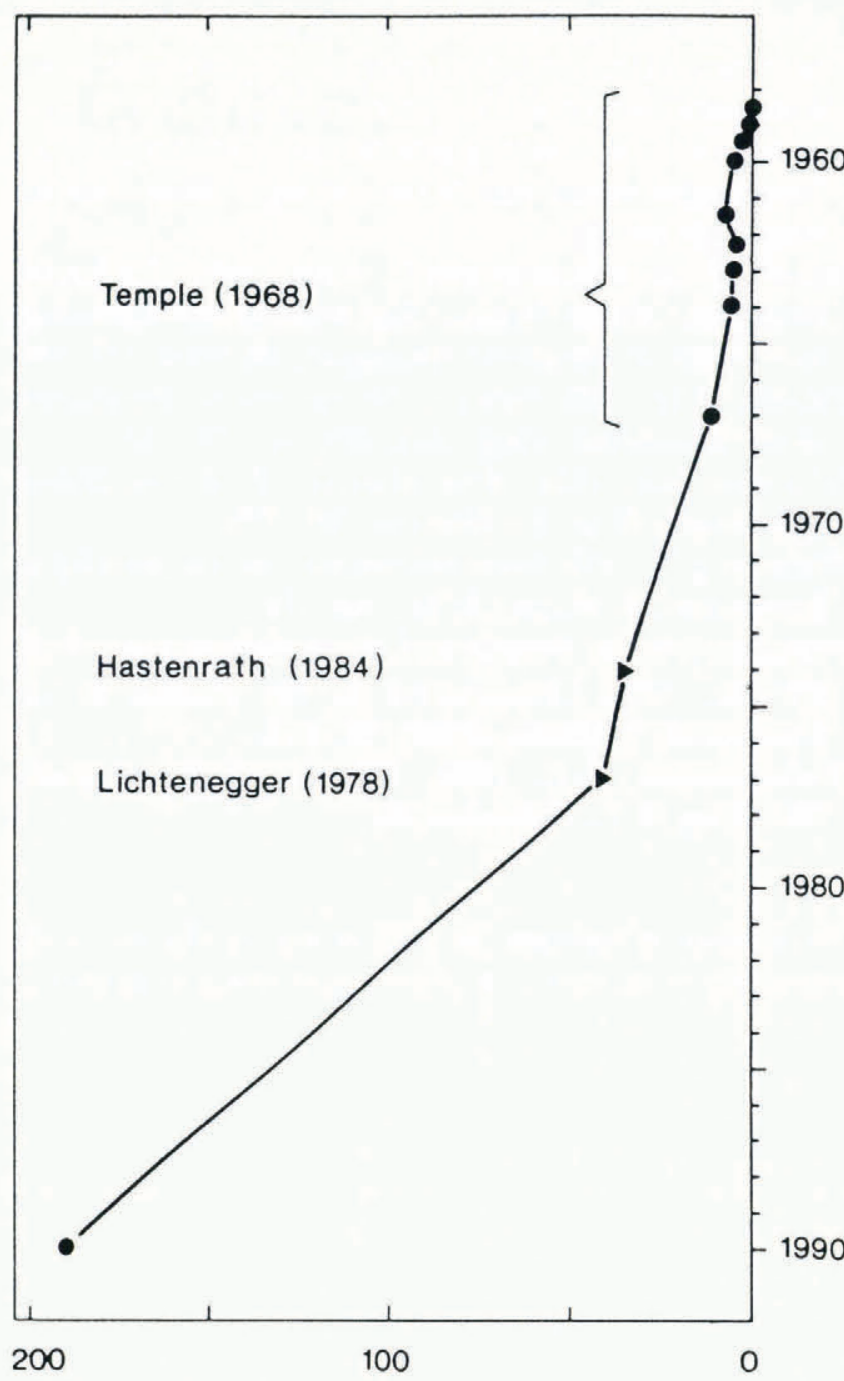

terminus fluctuations $(\mathrm{m})$

Fig. 7. Terminus fluctuations of Speke Glacier between January 1958 and January 1990 based on measurements from mark $D$ (dots) (Temple, 1968; data in this paper) and from assessments of photographs (triangles) (Lichtenegger and Lichtenegger, 1978; Hastenrath, 1984).

observed on the similar-sized Lewis Glacier of Mount Kenya since 1974 (Patzelt and others, 1985; Hastenrath and others, 1989).

Looking for the reasons of the fluctuations of tropical glaciers, Patzelt and others (1985), and also Kruss and Hastenrath (1987), suggested that significant decreases in precipitation have caused the general recent glacier recession observed on Mount Kenya, which is also situated in tropical East Africa. Temple (1968) suggested that increased amounts of precipitation, which are evident in the run-off records of Mubuku River and which were also reported by Fantin (1968) and by Osmaston and Pasteur (1972), caused the small advances of both Elena and Speke Glaciers around 1960. The fluctuations of glaciers in the Peruvian Cordillera Blanca correlate with observed change in both precipitation and air temperature (Kaser and others, 1990).

Assuming that the change of precipitation may be considered as controlling the general recession of Speke Glacier, this can hardly explain the differences in the behaviour of its entire western and eastern sections as shown in Figure 6. Spatial differences in the behaviour of the snout have already been observed and discussed by Temple (1968) and the studies carried out on Mount Kenya by Kruss and Hastenrath (Kruss and Hastenrath, 1987; Hastenrath and Kruss, 1988; Kruss and Hastenrath, 1990) confirm Temple's observations not only for the snout but also for the entire glacier.

A decrease in precipitation is normally associated with a decrease in vapour pressure and with decreased cloud cover. This leads to an increased amount of absorbed shortwave radiation, especially during the drier seasons. It is not only the varying degree of cloud cover that leads to local variance of absorbed solar radiation but variable topographic shading as well. The eastern section of Speke Glacier is protected against incident shortwave radiation for two reasons: in the morning by topographical shading and in the afternoon by convective cloud cover. In contrast to this, the western section receives much more solar radiation during the morning hours.

The precise reasons for the fluctuations of Speke Glacier will remain unresolved as long as the present lack of information on regional climate, mass balance and ice flow continues.

\section{ACKNOWLEDGEMENTS}

The authors thank $H$. Wagner for the photograph in Figure 6, S. Hastenrath, whose review resulted in a significant improvement in the clarity of this paper, and A.J. Gow and M. Kuhn, who improved the English.

\section{REFERENCES}

Allison, I. and J. A. Peterson. 1976. Ice areas on Mt. Jaya: their extent and recent history. In Hope, G. S., J. A. Peterson, U. Radok and J. Allison, eds. The equatorial glaciers of New Guinea. Rotterdam, A. A. Balkema, 27-38. Allison, I. and J. A. Peterson. 1989. Glaciers of Irian Jaya, Indonesia. U.S. Geol. Surv. Prof. Pap. 1386 H, 1-20.

Bergström, E. 1955. British Ruwenzori Expedition, 1952. Glaciological observations - preliminary report. $\mathcal{J}$. Glaciol., 2(17), 468-476.

Fantin, M. 1968. Sui ghiacciai dell'Africa. Bologna, Cappelli.

Fiory-Ceccopieri, M.R. 1981. Dal Caucaso al Himalaya 1889-1909. Milan, Touring Club Italiano.

Haeberli, W., H. Bösch, K. Scherler, G. Østrem and C. C. Wallén, eds. 1989. World glacier inventory; status 1988. Wallingford, Oxfordshire, IASH Press; Nairobi, GEMSUNEP; Paris, UNESCO.

Hastenrath, S. 1984. The glaciers of equatorial East Africa. Dordrecht, etc., D. Reidel Publishing Company.

Hastenrath, S. and P.D. Kruss. 1988. The role of radiation geometry in the climate response of Mount Kenya's glaciers. Part 2. Sloping versus horizontal surfaces. J. Climatol., 8(6), 629-639.

Hastenrath, S., R. Rostom and R. A. Caukwell. 1989. Variations of Mount Kenya's glaciers 1963-87. Erdkunde, 43(3), 202-210.

Humphreys, G. N. 1927. New routes on Ruwenzori. Geogr. J., $69(6), 516-531$. 
Humphreys, G.N. 1933. Ruwenzori: flights and further exploration. Geogr. 7., 82(6), 481-514.

Kaser, G., A. Ames and M. Zamora. 1990. Glacier fluctuations and climate in the Cordillera Blanca, Peru. Ann. Glaciol., 14, 136-140.

Kruss, P.D. and S. Hastenrath. 1987. The role of radiation geometry in the climate response of Mount Kenya's glaciers. Part 1. Horizontal reference surfaces. 7. Climatol., 7(5), 493-505.

Kruss, P.D. and S. Hastenrath. 1990. The role of radiation geometry in the climate response of Mount Kenya's glaciers. Part 3. The latitude effect. 7. Climatol., 10(3), 321-328.

Lichtenegger, J. and B. Lichtenegger. 1978. In der Wetterküche des Ruwenzori. Die Alpen. Zeitschrift des Schweizer Alpen-Club, 54(3), 119-126.

Luigi Amadeo, Duke of the Abruzzi. 1909. Der Ruwenzori. Erforschung und erste Ersteigung seiner höchsten Gipfel. Leipzig, F. A. Brockhaus.

Menzies, I. R. 1951. Some observations on the glaciology of the Ruwenzori Range. 7. Glaciol., 1(9), 511-512.

Messerli, B. 1980. Mountain glaciers in the Mediterranean area and in Africa. International Association of Hydrological Sciences Publication 126 (Workshop at Riederalp - World
Glacier Inventory), 197-211.

Osmaston, H.A. and D. Pasteur. 1972. Guide to the Ruwenzori. Oxford, Alden Press.

Patzelt, G. 1987. Die gegenwärtige Veränderung an Gebirgsgletschern der Erde. Frankf. Beitr. Didakt. Geogr., 10, 41-50.

Patzelt, G., E. Schneider and G. Moser. 1985. Der LewisGletscher, Mount Kenya. Begleitworte zur Gletscherkarte 1983. Z. Gletscherkd. Glazialgeol., 20, 1984, 177-195.

Temple, P.H. 1968. Further observations on the glaciers of the Ruwenzori. Geogr. Ann., 50A(3), 136-150.

Whittow, J.B. 1959. The glaciers of Mount Baker, Ruwenzori. Geogr. 7., 125(3-4), 370-379.

Whittow, J. B. 1960. Some observations on the snowfall of Ruwenzori. 7. Glaciol., 3(28), 765-772.

Whittow, J. B., A. Shepherd, J. E. Goldthorpe and P. H. Temple. 1963. Observations on the glaciers of the Ruwenzori. 7. Glaciol., 4(35), 581-616.

Wielochowsky, A.L. 1989. Ruwenzori map and guide. Worthing, A. L. Wielochowsky.

The accuracy of references in the text and in this list is the responsiblity of the authors, to whom queries should be addressed. 